\title{
A major milestone for Translational Cancer Research: indexing in PubMed/PubMed Central
}

It is with great pleasure, I announce that Translational Cancer Research (TCR) has reached a major milestone and is now indexed in PubMed/PubMed Central (PMC). All publications since 2019 will be available henceforth in PubMed/PMC, thus allowing maximum exposure to all articles published in TCR.

TCR began with a motto to successfully advance clinical medicine by focusing on novel therapeutic interventions and clinical trials to evaluate new treatment paradigms for cancer. The editors, the international advisory group of scientists and clinicians have since been working endlessly to ensure that all articles in TCR adhere to high scientific standards. The editorial board of TCR consists of 143 worldwide experts as members, including the Editor-in-Chief, the Co-Editor-in-Chief, and the Associate Editors-in-Chief. The editorial board members span over various countries including North America, Asia, Europe, South America, and Oceania. Up until now, TCR has published 101 issues, including 40 focused issue/special series on various topics (https://tcr.amegroups.com/post/category/special-series). Till date, TCR's articles have been cited 5,035 times by articles indexed in Web of Science Core Collection. In 2020 alone, TCR had 263,331 visitors and the total page views was 920,382. Readers were from diverse countries, the majority being from USA, followed by China, India and UK.

TCR has touched several milestones since its first issue in June 2012. I would like to take this opportunity to reflect on some of the important ones from the past nine and half years.

June, 2012: the first volume of TCR was published. It continued to publish bi-monthly from 2012-2019.

June, 2013: visibility to the international communities is one of the first milestones for any journal and to this end TCR was exhibited at the ASCO's 49th Annual Meeting at McCormick Place in Chicago, Illinois, as an international, open access, peerreviewed journal dedicated to translational cancer research, and the editorial board members, reviewers, authors and readers were introduced.

August, 2015: TCR was included in Scopus database which is the largest abstract and citation database of peer-reviewed literature, featuring smart tools to track, analyze and visualize research for the scientific community. TCR was evaluated by Scopus as "a well presented journal with high quality content".

October, 2015: TCR was accepted for coverage in Science Citation Index Expanded (SCIE), service of Thomson Reuters, by which all TCR articles started to get indexed in the database and was searchable online at the Web of Knowledge ${ }^{\mathrm{TM}}$ core collection.

September, 2019: TCR started publishing monthly.

October, 2019: commencement of the application of the CARE Guideline as reporting standards in TCR for completeness and transparency of published case reports. Authors submitting case-reports were asked to adhere to the CARE Checklist as an aid to authors in order to entirely and transparently let reviewers and readers know what authors did and found.

March, 2020: a transparent peer review process was implemented as an option for all manuscripts submitted to TCR. If opted, it allowed the inclusion of a "peer review file" (a record of reviewer reports and author replies) in the footnote of the corresponding article.

July, 2021: TCR was included within the list of the Committee on Publication Ethics (COPE) membership. TCR follows and promotes the highest standards of publication ethics and applies the COPE principles outlined in the core practices.

December, 2021: TCR passed the scientific quality review by the US National Institutes of Health's National Library of Medicine (NLM) for PubMed Central and is now indexed in PubMed/PMC, two of the most important and extensive biomedical digital databases.

As a scientific journal, our goal has consistently been publishing some of the most important works in the field of cancer research. We are tremendously proud of all the diligence put in by all our authors and are extremely humbled to see that our efforts have been recognized and appreciated by the scientific and international communities. In the coming years, we will be extending and enhancing the curriculum of topics we have covered, and continue to upgrade resources for authors and reviewers. We will look forward to welcoming newer opportunities for all researchers towards an improved and better TCR in the coming years. 
Wishing all our authors, reviewers, and readers a very prosperous and safe 2022!

Happy New Year!

\section{Acknowledgments}

Funding: None.

\section{Footnote}

Provenance and Peer Review: This article was commissioned by the Editorial Office, Translational Cancer Research. The article did not undergo external peer review.

Conflicts of Interest: The author has completed the ICMJE uniform disclosure form (available at https://tcr.amegroups.com/ article/view/10.21037/tcr-22-20/coif). EYC serves as the Editor-in-Chief of Translational Cancer Research. The author has no other conflicts of interest to declare.

Ethical Statement: The author is accountable for all aspects of the work in ensuring that questions related to the accuracy or integrity of any part of the work are appropriately investigated and resolved.

Open Access Statement: This is an Open Access article distributed in accordance with the Creative Commons AttributionNonCommercial-NoDerivs 4.0 International License (CC BY-NC-ND 4.0), which permits the non-commercial replication and distribution of the article with the strict proviso that no changes or edits are made and the original work is properly cited (including links to both the formal publication through the relevant DOI and the license). See: https://creativecommons.org/licenses/by-nc$\mathrm{nd} / 4.0 /$.

Eric Y. Chuang, Sc.D., EMBA

Graduate Institute of Biomedical Electronics and Bioinformatics, National Taiwan University, Taipei, Taiwan.

(Email: chuangey@ntu.edu.tw)

Submitted Dec 28, 2021. Accepted for publication Jan 05, 2022.

doi: $10.21037 /$ tcr-22-20

View this article at: https://dx.doi.org/10.21037/tcr-22-20

Cite this article as: Chuang EY. A major milestone for Translational Cancer Research: indexing in PubMed/PubMed Central. Transl Cancer Res 2022;11(1):1-2. doi: 10.21037/tcr$22-20$ 